\title{
RNF217-AS1 Gene
}

National Cancer Institute

\section{Source}

National Cancer Institute. RNF217-AS1 Gene. NCI Thesaurus. Code C97903.

This gene may play a role in B-cell acute lymphoblastic leukemia. 